
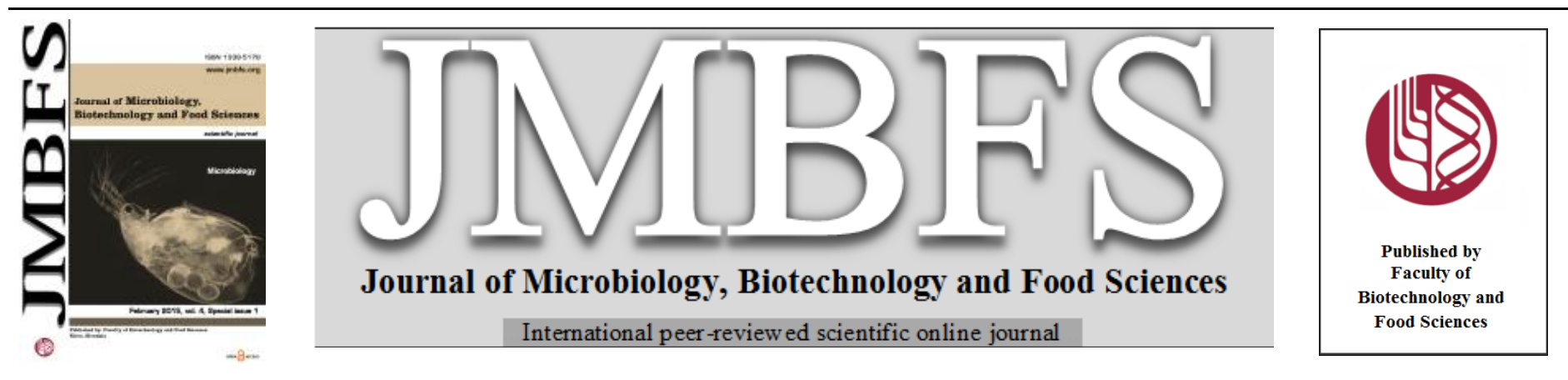

\title{
CHARACTERIZATION OF ENDOPHYTIC MICROFLORA OF ROSA CANINA FRUITS
}

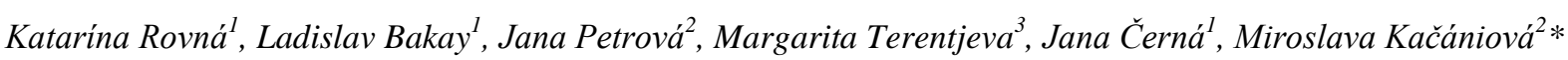

\section{Address(es):}

${ }^{1}$ Slovak UniversityofAgriculture in Nitra, Horticulture and Landscape Engineering Faculty, Department of Green's Biotechnics, Trieda Andreja Hlinku 2, 949 76, Nitra, Slovakia.

${ }^{2}$ Slovak University of Agriculture in Nitra, Faculty of Biotechnology and Food Sciences, Department of microbiology, Trieda Andreja Hlinku 2, 949 76, Nitra, Slovakia.

${ }^{3}$ Latvia University of Agriculture, Faculty of Veterinary Medicine, Institute of Food and Environmental Hygiene, K. Helmaņa iela 8, LV 3007, Jelgava, Latvia.

*Corresponding author: miroslava.kacaniova@gmail.com

doi: 10.15414/jmbfs.2015.4.special1.65-68

\section{ARTICLE INFO}

Received 4. 11. 2014

Revised 10. 12. 2014

Accepted 24. 12. 2014

Published 2. 2. 2015

Regular article open ${ }_{\text {ACCESS }}$

\begin{abstract}
There aren't a lot of studies about the bacterial communities associated with the Rosa canina and the aim of this study was to characterize endophytic bacteria from fruit of Rosa canina. The fruits of $R$. canina, which is growing wild in Slovakia, were collected in May 2013 from four locations: Nitra-Zobor, Vrbové-Baraní dvor, Rišňovce, Modra pažit, Slovakia. Microbiological analyses were conducted by use of standard microbiological methods by spreading of fruits homogenates onto agar plate. Total viable count and mesophilic anaerobic sporulating bacteria were determined on Plate Count Agar after incubation for 2 days at $37{ }^{\circ} \mathrm{C}$. Pseudomonas aeruginosa enumeration was carried out after incubation of Pseudomonas Isolation agar at $48 \mathrm{~h}$ at $35{ }^{\circ} \mathrm{C}$. For members of the family Enterobacteriaceae $\left(45^{\circ} \mathrm{C}\right)$ Violet Red Bile Glucose agar were used and incubation was carried out for $24 \mathrm{~h}$ at $37{ }^{\circ} \mathrm{C}$. For determinations of fungal colonies Malt agar and Czapek-Dox agar were inoculated using the spread-plate technique and incubated at 25 ${ }^{\circ} \mathrm{C}$ for 5 days. The yeasts were grown in Glucose Yeast Peptone agar (aerobiosis) at $25{ }^{\circ} \mathrm{C}$ during 72 hours. The total viable count of fruits ranged from $4.07 \mathrm{log}$ cfu. $\mathrm{g}^{-1}$ in Rišňovce to $4.84 \mathrm{log}$ cfu. $\mathrm{g}^{-1}$ in Vrbové Baraní dvor. Number of mesophilic anaerobic sporulating bacteria ranged from 4.09 in Vrbové Baraní dvor to $4.82 \mathrm{log} \mathrm{cfu}^{-1} \mathrm{~g}^{-1}$ in Modrá pažit'. Number of Pseudomonas aeruginosa count ranged from 2.00 in Nitra Zobor and Vrbové Baraní dvor to $3.94 \log \mathrm{cfu}^{-\mathrm{g}^{-1}}$ in Modrá pažit'. In our study the number of Enterobacteriaceae genera ranged from 3.38 in Nitra Zobor to $4.25 \mathrm{log}$ cfu.g $^{-1}$ in Vrbové Baraní dvor. Number of yeasts ranged from 3.36 in Vrbové Baraní dvor to $3.85 \log$ cfu.g ${ }^{-1}$ in Modrá pažit'. Number of microscopic filamentous fungi ranged from 2.60 in Modrá Pažit' to $3.52 \log$ cfu. $\mathrm{g}^{-1}$ in Nitra Zobor. Our findings indicate that Rose plant is naturally associated with a variety of endophytic microorganisms, which have different physiological and biochemical properties.
\end{abstract}

Keywords: Rosa canina, fruits, microbiological properties, bacteria, yeasts, microscopic filamentous fungi

\section{INTRODUCTION}

The genus Rosa contains over 100 species that are widely distributed in Europe, Asia, the Middle East and North America. These deciduous shrubs are widely grown in gardens for their flowers and fruits. The plants show strong resistance to hard environmental conditions as rocky, inclined places, poor soils and limiting water (OzturkYilmaz and Ercisli, 2011).

The study of plant bacterial endophytes is important for understanding ecological interactions and to develop biotechnological applications. The term "endophyte" refers to interior colonization of plants by bacterial or fungal microorganisms. Endophytic bacteria are defined as bacteria that colonize healthy plant tissue without causing obvious disease symptoms in host plant (Hallmann et al., 1997) Endophytic bacteria seem to be ubiquitous in most plant species and have been isolated from roots, leaves, stems, flowers, fruits and seeds (Lodewyckx $\boldsymbol{e t}$ al., 2002). Endophytic bacteria may promote certain metabolic properties, such as enhance plant growth, controlling soilborne pathogens or helping host plant to develop stress responses to environmental abuse (Mastretta et al., 2006; Taghavi et al., 2007; Ryan et al., 2008). Furthermore, the interactions between plants and bacteria help plants to settle in ecosystem restoration processes (Glick et al., 1995). These interactions may increase the ability of plants to utilize nutrients from the soil by increasing root development, uptaking nitrate, solubilizing phosphorus or controling soil-borne pathogens (Whipps, 2001).

The endophytes often originate from the soil. They initially infecting the host plant by colonizing, for instance, the cracks had been formed formed in lateral root junctions. Then the endophytes quickly spreading to the intercellular spaces in the root (Chi et al., 2005). Although other portals of entry as wounds caused by microbial or nematode phytopathogens, or the stomata found in leaf tissue into the plant exist (McCulleyet al., 2004), root cracks are recognized as the main 'hot spots' for bacterial colonization. Hence, endophytes that infect plants from soil to be ecologically successful must be competent root colonizers. Although it is generally assumed that many bacterial endophyte communities are the product of a colonizing process initiated in the root zone (Sturzet al., 2000), they may also originate from other source than the rhizosphere, such as the phyllosphere, the anthosphere, or the spermosphere (Hallman, et al., 1997).

The variations in the endophytic bacterial communities can be attributed to plant age, plant source, tissue type, time of sampling, and environment condition (Kobayashi and Palumbo, 2000). Thamizh Vendan et al. (2010) showed that the age of the plant could largely influence the variation in the endophytic community of ginseng plants. Also variation in endophytic diversity might be a function of the different maturation stages specific to each plant, which might influence the different types and amounts of root exudates (Ferreira $\boldsymbol{e t}$ al., 2008).

The aim of our study was to detect population of microorganisms on Rosa canina fruits from four different localities.

\section{MATERIAL AND METHODS}

\section{Plant material}

The fruits of R. canina, which is growing wild in Slovakia, was collected in May 2013 from Nitra-Zobor, Vrbové-Baraní dvor, Rišňovce, Modra pažit locations in Slovakia. 


\section{Microbiological analysis}

Microbiological analyses were conducted by use of standard microbiological methods by spreading of fruits homogenates onto agar plate. Total viable coun (TVC) and mesophilic anaerobic sporulating bacteria (MASB) were determined using Plate Count Agar (PCA, Oxoid, UK), which was incubated for 2 days at 37 ${ }^{\circ} \mathrm{C}$. PCA plates for TVC were incubated aerobically, while the incubated plates for cultivation of MASM in an aerobic atmosphere supplemented with carbon dioxide. For Pseudomonas aeroginosa enumerations, a $0.1 \mathrm{ml}$ from 1:10 prepared serial dilutions of petals and fruits homogenates in $0.1 \%$ physiological solution was spread onto the surface of solid media. Pseudomonads were determined on Pseudomonas Isolation agar (PIA, Oxoid, UK) after incubation at $48 \mathrm{~h}$ at $35{ }^{\circ} \mathrm{C}$ by detection of blue or blue-green pyocyanin pigment of Pseudomonas aeruginosa, which diffuses into the surrounding medium. For members of the family Enterobacteriaceae, a $1.0 \mathrm{ml}$ sample was inoculated into $10 \mathrm{ml}$ of molten $\left(45^{\circ} \mathrm{C}\right.$ ) Violet Red Bile Glucose agar (VRBG, Oxoid, UK) by overlaying of sampling material with molten agar. After inoculation agar was incubated at $37^{\circ} \mathrm{C}$ for $24 \mathrm{~h}$. The large colonies with purple haloes were counted. For determinations of fungal colony of petals and fruits were soaked in $9.9 \mathrm{~m}$ sterile tap water containing $0.02 \%$ Tween 80 and then 30 min shaked on shaker Petri dishes of Malt agar and Czapek-Dox agar were inoculated by using the spread-plate technique and incubated at $25^{\circ}$ for 5 days of incubation. The yeasts were grown in Glucose Yeast Peptone agar (aerobiosis), at $25{ }^{\circ} \mathrm{C}$ during 72 hours. All plates were examined for typical colony types and morphology characteristics for each agar was applied.

\section{Statistical analysis}

For data from each replication the mean was calculated and all data were log transformed. Statistical analysis was done with STATGRAPHICS 5 software (UMEX GmbH Dresden, Germany). For number of total viable count, mesophilic anaerobic sporulating bacteria, Pseudomona aeruginosa, Enterobacteriaceae, microscopic filamentous fungi and yeast standard deviation (SD) and coefficien of variability $(\mathrm{CV})$ were calculated. For differences in a numbers of bacteria in fruits collected from different sampling location Student's t-test was calculated and samples were accepted as significantly different if $\mathrm{P}<0.05$.

\section{RESULTS AND DISCUSSION}

Plant communities in arid habitat are controlled by the interaction between biotic and physicochemical components of the desert matrix (Read, 1998). Interactions with microbes appear crucial in obtaining inorganic nutrients or growthinfluencing substances. Despite the important role played by bacterial diversity in such plant communities, little is known on the distribution and abundance of endophytic

bacteria in rose plant growing in such habitat. Rose plant has been studied with respect to its endophytic fungi characteristics (Catalina Salgado et al., 2007) However, no study has been reported to the relationships between rose plant and their associated endophytic bacteria. The purpose of this study is to isolate and characterize endophytic bacteria from rose plant collected from rose farm, and to assess isolates plant growth promoting (PGP) traits like production of IAA and siderophore, and phosphate solubilization. This study is the first report on

the diversity of culturable endophytic bacteria associated with the rose plant growing in arid habitat. The outcome of this study will form the basis for the selection of endophytic bacteria that can be utilized for the facilitation of plant growth in such habitat.

Total viable count (TVC) values for the tested groups of $R$. canina fruits are showed in Tab. 1. The total viable count of fruits ranged from $4.07 \mathrm{log} \mathrm{cfu}^{-1} \mathrm{~g}^{-1}$ in Rišňovce to $4.84 \log$ cfu.g ${ }^{-1}$ in Vrbové Baraní dvor and TVC values for the tested groups of $R$. canina fruits are shown in Table. 1. Significant differences in a number of TVC between all tested group were not found $(\mathrm{P}>0.05)$.

Table 1 Number of total viable count of Rosa canina fruits in $\log$ cfu.g ${ }^{-1}$

\begin{tabular}{lccccc}
\hline \hline Locality & Mean & SD & CV\% & Min & Max \\
\hline \hline Nitra-Zobor & 4.68 & 0.01 & 0.21 & 4.67 & 4.69 \\
Vrbové-Baraní dvor & 4.83 & 0.02 & 0.32 & 4.81 & 4.84 \\
Rišňovce & 4.08 & 0.01 & 0.14 & 4.07 & 4.08 \\
Modrá pažit' & 4.76 & 0.03 & 0.56 & 4.74 & 4.79 \\
\hline \hline SD - standard deviation, CV - coefficient of variation, min - minimum, max - maximum
\end{tabular}

Indeed, the major key to succeed in isolating and studying endophytes is to ensure the sterility of the plant surface (Hallmann et al., 1997). The diversity of isolated endophytic bacteria is also largely dependents on the isolation methods (Das et al., 2007). The number of colony forming units per gram fresh weight of culturable endophytic bacteria isolated from various plant organs of Rose plant was determined in study of Ell-Deep et al. (2011). The results showed that CFU value in flower $\left(1.2 \times 10^{2}\right)$ is much lower than in leaves $\left(2.4 \times 10^{3}\right)$ of Rose plants. In contrast, root $\left(4.6 \times 10^{4}\right)$ and stems $\left(3.1 \times 10^{4}\right)$ had higher CFU values than other organs. This distribution pattern then the plant parts harbor higher numbers of endophytes confirms and extends results reported previously (Das et al., 2007).
Furthermore, our results indicated that PCA supported more of endophytic bacterial growth than PDA as previously reported by Hung and Annapurna (2004).

Number of mesophilic anaerobic sporulating bacteria (MASB) of tested groups of $R$. canina fruits are shown in Table 2. Number of mesophilic anaerobic sporulating bacteria ranged from 4.09 in Vrbové Baraní dvor to $4.82 \log _{\text {cfu. }} \mathrm{g}^{-1}$ in Modrá pažit'. Statistically significant difference was not found between all tested groups $(\mathrm{P}>0.05)$.

Table 2 Number of mesophilic anaerobic sporulating bacteria of Rosa canina fruits in $\log$ cfu.g $\mathrm{g}^{-1}$

\begin{tabular}{lccccc}
\hline \hline Locality & Mean & SD & CV\% & Min & Max \\
\hline \hline Nitra-Zobor & 4.79 & 0.02 & 0.42 & 4.77 & 4.81 \\
Vrbové-Baraní dvor & 4.14 & 0.05 & 1.21 & 4.09 & 4.19 \\
Rišňovce & 4.73 & 0.01 & 0.21 & 4.72 & 4.74 \\
Modrá pažit' & 4.80 & 0.02 & 0.42 & 4.78 & 4.82 \\
\hline \hline
\end{tabular}

SD - standard deviation, CV - coefficient of variation, min - minimum, max - maximum

Endophytic bacteria have been isolated from a large diversity of plants was reviewed by Sturz et al. (2000). Mundt and Hinkle (1976) reported as many as 46 different bacterial species from 27 plant species. In planta and ex planta populations of Pseudomonas species could be differentiated by biochemical characteristics (van Peer et al., 1990). McInroy and Kloepper (1991) showed that the endophytic bacterial

populations in corn stems ranged from $1 \times 10^{3}$ initially to $1 \times 10^{10}$ cfu.ml ${ }^{-1}$ after 10 week. Bacteria belonging to the genera Bacillus and Pseudomonas are easy to culture, and cultivation dependent studies have identified them as frequently occurring endophytes (Seghers et al., 2004).

Number of Pseudomonas aeruginosa for tested groups of $R$. canina fruits is shown Table 3. Number of Pseudomonas aeruginosa count ranged from 2.00 in Nitra Zobor and Vrbové Baraní dvor to $3.94 \log \mathrm{cfu} . \mathrm{g}^{-1}$ in Modrá pažit' Number of Pseudomona aeruginosa isolated from different sampling location was significantly different $(\mathrm{P}<0.05)$.

Table 3 Number of Pseudomonas aeruginosa count of Rosa canina fruits in log cfu.g ${ }^{-1}$

\begin{tabular}{lccccc}
\hline \hline Locality & Mean & SD & CV\% & Min & Max \\
\hline \hline Nitra-Zobor & 2.02 & 0.03 & 1.24 & 2.00 & 2.05 \\
Vrbové-Baraní dvor & 2.80 & 0.14 & 6.93 & 2.00 & 2.25 \\
Rišňovce & 2.62 & 0.30 & 11.56 & 2.30 & 2.90 \\
Modrá pažit' & 3.91 & 0.04 & 1.07 & 3.86 & 3.94 \\
\hline \hline
\end{tabular}

SD - standard deviation, CV - coefficient of variation, min - minimum, max - maximum

In the study of Hashidoko et al. (2002) five Gram-negative bacteria of Enterobacteriaceae family were isolated from the phyllosphere of green or senescing leaves of Rosa rugosa, and their phenotypic and physiological characteristics were examined. Partial 16S rDNA sequencing led to identification of these isolates as Pantoea agglomerans, Klebsiella terrigena, Erwinia rhapontici, and two strains of Rahnella aquatilis. Interestingly, that these hyllosphere bacteria had certain phenotypic and physiological convergences showing their own metabolic properties of phenolic compounds of plant origin In particular, the two Ra. aquatilis isolates from the green leaves had a substrateinducible gallate decarboxylase activity in the resting cells that had been cultured in $1 \mathrm{mM}$ gallic acid- or protocatechuic acid-containing medium. The other three isolates from the senescing leaves did not express this enzyme activity. Simple phenolics that $R a$. aquatilis decarboxylatively produced from benzoic acid derivatives had better antimicrobial activities than those of the substrates.

In our study the number of Enterobacteriaceae genera ranged from 3.40 in Rišňovce to $4.25 \log$ cfu. $^{-1}$ in Vrbové Baraní dvor. Number of family Enterobacteriaceae of Rosa canina fruits is shown in Table 4. Statistically significant difference was not found between all testing groups (P.>0.05)

\begin{tabular}{lccccc}
\multicolumn{6}{l}{ Table 4 Number of Enterobacteriaceae genera of $R$. canina fruits in log cfu.g ${ }^{-1}$} \\
\hline \hline Locality & Mean & SD & CV\% & Min & Max \\
\hline \hline Nitra-Zobor & 3.78 & 0.06 & 1.65 & 3.71 & 3.83 \\
Vrbové-Baraní dvor & 4.21 & 0.04 & 0.90 & 4.18 & 4.25 \\
Rišňovce & 3.43 & 0.03 & 0.73 & 3.40 & 3.45 \\
Modrá pažit' & 3.77 & 0.21 & 5.68 & 3.52 & 3.90 \\
\hline \hline
\end{tabular}

SD - standard deviation, CV - coefficient of variation, min - minimum, max - maximum

The existence of true highly specialized endophytic species is closely associated with the tissues of certain plants and is unlikely among the yeasts. Most yeast fungi are typical copiotrophs, requiring sufficiently high concentrations of easily accessible compounds for growth. Therefore, yeast development is most probable in the sugar-containing tissues of plants under storage condition, such as the parenchymal tissue of succulent fruits. In recent study of Isaeva et al. (2009) the yeast communities of sugary fruits indeed demonstrated the constant presence of yeasts in their tissues, and they typically belonged to the same species as on the 
surface. The yeasts are most abundant in the fruits which are easily penetrable due to the incompletely coalesced hypanthium, thin exocarp, damage done to them on ripening, etc. Also was established that yeasts might also be present in the fruits with a thick dense covering. For example, it was found that yeasts (up to $10^{7} \mathrm{CFU}^{-1} \mathrm{~g}^{-1}$ ) developed in the cotyledons of whole intact oak acorns at certain stages of their ripening (Isaeva et al., 2009).

It was shown earlier that yeasts are regularly found in the internal tissues of many succulent fruits and their number sharply increasing after fruit ripening. In this process the yeasts growing in the fruit flesh are represented by the same species as those on the surface. One of the variants of such a nonspecific endophytic yeast community was studied by us by the example of the fruits of the wild rose. As a rule, succulent fruits do not possess dense covering. Therefore, it is possible for the epiphytic yeast cells to penetrate regularly in to the fruits as the result of microscopic disruption of the integrity of their covering tissues. A similar taxonomic composition and the specifics of the seasonal dynamics of the yeast groups on the fruit surface and inside them are the consequence of this (Isaeva et al., 2009).

Number of yeasts for tested groups of $R$. canina fruits shown in Table 5. Number of yeasts ranged from 3.36 in Vrbové Baraní dvor to $3.85 \mathrm{log}$ cfu.g ${ }^{-1}$ in Modrá pažit'. Statistically significant difference was not found between tested samples $(\mathrm{P}>0.05)$.

Table 5 Number of yeasts of Rosa canina fruits in $\log$ cfu. $\mathrm{g}^{-1}$

\begin{tabular}{lccccc}
\hline Locality & Mean & SD & CV\% & Min & Max \\
\hline \hline Nitra-Zobor & 3.46 & 0.07 & 2.13 & 3.38 & 3.52 \\
Vrbové-Baraní dvor & 3.40 & 0.04 & 1.03 & 3.36 & 3.43 \\
Rišňovce & 3.77 & 0.04 & 1.07 & 3.73 & 3.81 \\
Modrá pažit' & 3.82 & 0.04 & 0.99 & 3.78 & 3.85 \\
\hline \hline
\end{tabular}

SD - standard deviation, CV - coefficient of variation, min - minimum, max - maximum

Number of microscopic filamentous fungi for tested groups of $R$. canina fruits is shown Table 6. Number of microscopic filamentous fungi ranged from 2.60 in Modrá Pažit' to $3.52 \log$ cfu.g $^{-1}$ in Nitra Zobor. Statistically significan differences were not found between tested samples $(\mathrm{P}>0.05)$.

Table 6 Number of microscopic filamentous fungiof Rosa canina fruits in log cfu.g $\mathrm{g}^{-1}$

\begin{tabular}{lccccc}
\hline \hline Locality & Mean & SD & CV\% & Min & Max \\
\hline \hline Nitra-Zobor & 3.48 & 0.05 & 1.30 & 3.43 & 3.52 \\
Vrbové-Baraní dvor & 2.88 & 0.09 & 3.04 & 2.78 & 2.95 \\
Rišňovce & 3.01 & 0.14 & 4.52 & 2.85 & 3.09 \\
Modrá pažit' & 3.04 & 0.41 & 13.34 & 2.60 & 3.40 \\
\hline \hline
\end{tabular}

SD standard deviation, $\mathrm{CV}$ coefficient of variation, min minimum, max maximum

Plants provide nutrients and stable environmental conditions that are vital for the development of fungi. In turn, fungi excrete secondary metabolites that protect plants from phytopathogens and phytophages. It was demonstrated that endophytic fungi can enhance the plant resistance to diseases and unfavorable conditions (Blagoveshchenskaya, 2006). It is believed that the capacity of fungi for endophytic growth is the result of plant evolution, i.e., the transition from an aquatic environment to a terrestrial, and represents implementation of the strategy aimed at eliminating the adverse effects exerted by the ambient environment (particularly by solar radiation and aridization). The constant or varying development of microorganisms under relatively stable and nutrient rich conditions inside plant tissues is considered the result of their long term coevolution (Hirano and Upper, 2000; Isaeva et al., 2009).

\section{CONCLUSION}

Results of our work suggest that Rose plant is naturally associated with a variety of endophytic microorganisms, which have different physiological and biochemical capabilities. All groups of microorganisms - total viable count, mesophilic anaerobic sporulating bacteria, Pseudomonas aeruginosa, Enterobacteriaceae and microscopic filamentous fungi were found in all the samples of Rosa canina were tested. Their numbers varied depending on the sampling collecting location, with the lowest numbers of total viable count were found in the Rišňovce area and the highest levels of total viable count were found in the Vrbové Baraní dvor area. The lowest number of mesophilic anaerobic sporulating bacteria was found in Vrbové Baraní dvor and higher in Modrá pažit'. Number of Pseudomonas aeruginosa count was the lowest in Nitra Zobor and Vrbové Baraní dvor and highest in Modrá pažit'. The lowest number of Enterobacteriaceae genera was found in Rišňovce and hishest number in Vrbové Baraní dvor.Number of yeasts was the lowest in Vrbové Baraní dvor and the highest in Modrá pažit'. The lowest number of microscopic filamentous fungi was found in Modrá Pažit' and the highest in Nitra Zobor.

This study is the first report on the diversity of culturable endophytic bacteria associated with the rose plant growing in arid habitat. The outcome of this study will form the basis for the selection of endophytic bacteria that can be utilized for the facilitation of plant growth in such habitat.
Acknowledgments: The paper was supported by the project: The research leading to these results has received funding from the European Community under project no 26220220180: Building Research Centre „AgroBioTech“, by grant of VEGA 1/0611/14 and by grant of KEGA 012SPU-4/2013.

\section{REFERENCES}

BLAGOVESHCHENSKAYA, E.Y. 2006.Endophytic Fungi of Cereals, Extended Abstract of Cand. Sci. (Biol.) Dissertation, Moscow: Mosk. Gos. Univ., 2006.

CATALINA SAlGADO, S., CARIDAD CEPERO, M., REALPE, M., RESTREPO, S. 2007. Histological analyses of the fungal endophytes in Rosa hybrid. Revista Iberoamericana de Micologia, 24, 323-324.

DAS, M., ROYER, T.V., LEFF, L.G. 2007. Diversity of fungi,bacteria, and actinomycetes on leaves decomposing in a stream. Applied and Environmental Microbiology, 73, 756-767. http://dx.doi.org/10.1128/aem.01170-06

EL-DEEB B., BAZAID,S., GHERBAWY, Y., ELHARIRY, H. 2012 Characterization of endophytic bacteria associated with rose plant (Rosa damascenatrigintipeta) during flowering stage and their plant growth promoting traits.Journal of $\quad$ PlantInteractions, $\quad 7(3), \quad 248-253$. http://dx.doi.org/10.1080/17429145.2011.637161

FERREIRA, J.L., MAGALHĂES, P.C, BORÉM, A. 2008.Evaluation of three physiologic characteristics in four cycles of selection in maize cultivar BRS-4154 under tolerance to water logging of the soil. Cięncia e Agrotecnologia,32, 17191723. http://dx.doi.org/10.1590/s1413-70542008000600006

GLICK, B.R., KARATUROVIC, D.M., NEWELL,P.C. 1995. A novel procedure for rapid isolation of plant growth promoting Pseudomonads. Canadian Journal of Microbiology, 41, 533-536. http://dx.doi.org/10.1139/m95-070 HALLMANN, J., QUADT-HALLMANN, A., MAHAFFEE, W.F., KLOEPPER, J.W. 1997 Bacterial endophytes in agricultural crops. Canadian Journal of Microbiology, 43 895-914. http://dx.doi.org/10.1139/m97-131

HASHIDOKO, Y., ITOH, E., YOKOTA, K., YOSHIDA,T., TAHARA, S 2002. Characterization of Five Phyllosphere Bacteria Isolated from Rosa rugosa Leaves, and Their Phenotypic and Metabolic Properties. Bioscience, Biotechnology, and Biochemistry, 66 (11), 2474-2478. http://dx.doi.org/10.1271/bbb.66.2474 HIRANO, S.S., UPPER, C.D. 2000.Bacteria in theLeaf Ecosystem with Emphasis on Pseudomonas syringaea Pathogen, IceNucleus, and Epiphyte. Microbiology and MolecularBiology Review, 64(3), 624-653.

HUNG, P.Q., ANNAPURNA,K. 2004. Isolation and characterizationofendophyticbacteria in soybean (glycinesp.).Omonrice, 12, 92 101.

CHI, F., SHEN, S.H., CHENG, H.P., JING, Y.X., YANNI, Y.G., DAZZO, F.B. 2005. Ascending migration of endophytic rhizobia, from roots to leaves, inside rice plants and assessment of benefits to rice growth physiology. Applied and Environm Microbiology, 71 ,

7271-7278 http://dx.doi.org/10.1128/aem.71.11.7271-7278.2005

ISAEVA, O.V., GLUSHAKOVA, A.M., YURKOV, A.M.. CHERNOV, I.Y 2009a. The Yeast Candida railenensis in the Fruits of English Oak (Quercusrobur L.) Microbiology, 78(3), 355-359. http://dx.doi.org/10.1134/s002626170903014x

KOBAYASHI, D. Y., PALUMBO, J. D. 2000. Bacterial endophytes and their effects on plants and uses in agriculture. In Microbial Endophytes (C. W. Bacon \& J. F. White, eds): 199-236. MarcelDekker, New York.

LODEWYCKX, C., MERGEAY, M., VANGRONSVELD, J., CLIJSTERS, H VAN DER LELIE,D. 2002. Isolation, characterization, and identification of bacteria associated with the zinc hyperaccumulator Thlaspicaerulescens subsp.calaminaria. International Journal of Phytoremediation, 4,101-115. http://dx.doi.org/10.1080/15226510208500076

MASTRETTA, C., BARAC, T., VANGRONSVELD, J., NEWMAN, L. TAGHAVI, S., VAN DER LELIE, D. 2006. Endophytic bacteria and their potential application to improve the phytoremediation of contaminated environments. Biotechnology, genetic engineering reviews, 23, 175-207.

MCCULlEY, R.L., ARCHER, S.R., BOUTTON, T.W., HONS, F.M., ZUBERER,D.A.2004. Soil respiration and nutrient cycling in wooded communities developing in grassland. Ecology, 85, 2804-2817.

MCINROY, J. A., KLOEPPER, J.W. 1995. Survey of indigenous bacterial endophytes f rom cotton and sweet corn. Plant Soil, 173,

$337-342$ http://dx.doi.org/10.1007/bf00011472

MUNDT, J.O. AND HINKLE, J.O. 1976. Bacteria within ovules and seeds. Applied and EnvironmentalMicrobiology, 32, 694-698.

OZTURK YILMAZ, S., ERCISLI, S. 2011. Antibacterial and antioxidant activity of fruits of some rose species from Turkey. Romanian Biotechnological Letters, 16(4), 6407-6411.

READ, D.J. 1998. Mycorrhizas and nutrient cycling in sand dune ecosystems Proceedings of Symposium. Edinburgh: The Royal Society of Edinburgh, 966 89-110.

RYAN, R.P., GERMAINE, K., FRANKS, A., RYAN, D.J., DOWLING,D.N 2008. Bacterial endophytes: recent developments and applications. FEMS 
Microbiological Letters, 278, 1-9. http://dx.doi.org/10.1111/j.1574. 6968.2007.00918.x

SEGHERS, D., WITTEBOLLE, L., TOP, E. M., VERSTRAETE, W., SICILIANO, S. D. 20

04. Impact of agricultural practices on the Zea mays L.

Endophyticcommunity. Applied and Environmental Microbiology, 70, 1475

1482. http://dx.doi.org/10.1128/aem.70.3.1475-1482.2004

STURZ, A. V., CHRISTIE, B. R., AND NOWAK, J. 2000. Bacterial endophytes:

Potential role in developing sustainable systems of crop production.Critical Reviews in Plant Sciences, 19,1-30. http://dx.doi.org/10.1016/s07352689(01)80001-0

TAGHAVI, S., GARAFOLA, C., MONCHY, S., NEWMAN, L., HOFFMAN A., WEYENS, N., BARAC, T., VANGRONSVELD, J., VAN DER LELIE,D. 2007. Genome survey and characterization of endophytic bacteria exhibiting a beneficial effect on growth and development of poplar trees.Applied and Environmental Microbiology, 75,748-757. http://dx.doi.org/10.1128/aem.0223908

THAMIZH VENDAN, R., YU, Y.J., LEE, S.H, RHEE, Y.H. 2010.Diversity of endophytic bacteria in ginseng and their potential for plant growth promotion. The Journal of Microbiology , 48(5), 559-65. http://dx.doi.org/10.1007/s12275-0100082-1

VAN PEER, R., PUNTE, H. L. M., DE WEGER, L. A., AND SCHIPPERS, B. 1990. Ch aracterization of root surface and endorhizosphere pseudomonads in relation to their colonization of roots. Applied and Environmental Microbiology, 56, 2462 2470 .

WHIPPS, J.M. 2001. Microbial interactions and biocontrol in the rhizosphere. Journal of Experimental Botany, 52, 487-511. http://dx.doi.org/10.1093/jexbot/52.suppl 1.487 